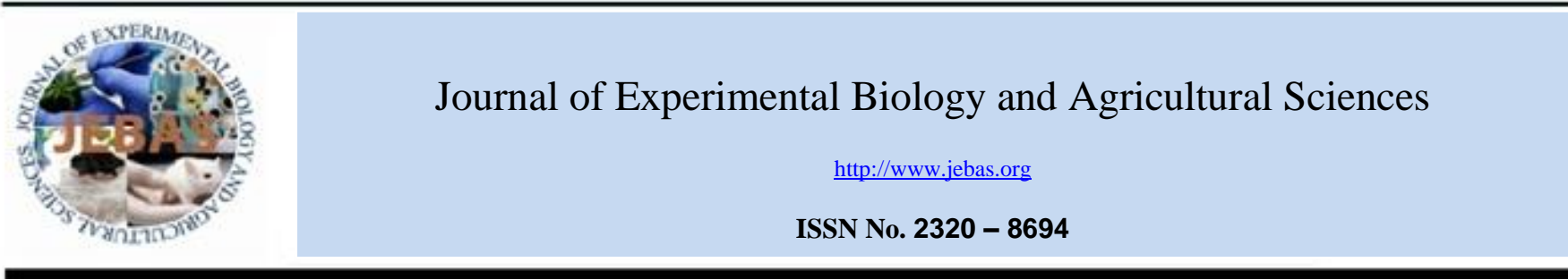

\title{
DISEASES, PESTS AND OTHER NATURAL ENEMIES OF INDIAN HONEY BEE (Apis cerana F.) IN KATRAIN AREA OF KULLU VALLEY, HIMACHAL PRADESH
}

\section{Nirupama Sharma*, JK Gupta, Harish Sharma}

Department of Entomology and Apiculture, Dr YS Parmar University of Horticulture and Forestry, Nauni-Solan 173230 (HP)

Received - August 25, 2018; Revision - September 23, 2018; Accepted - October 02, 2018

Available Online - October 5, 2018

DOI: http://dx.doi.org/10.18006/2018.6(5).895.897

\section{KEYWORDS \\ Apis cerana \\ Pests, diseases \\ Kullu Valley \\ Himachal Pradesh}

\begin{abstract}
Apis cerana colonies are attacked by various pseudoscorpians, ants and birds. An understanding of the incidence periods of different insect pests, diseases, predators and natural enemies on A. cerana colonies is essential for developing effective management strategies for a particular hamlet/niche. Therefore, present investigation was carried out to find out the information regarding different insect pests, diseases, predators and natural enemies of A. cerana in the apiaries of Regional Horticulture Research Sub-Station of Dr. Y.S. Parmar University of Horticulture and Forestry at Katrain, Kullu, Himachal Pradesh. Fifteen colonies, each on 5-6 frames were selected for the present study. Organisms collected from debris were identified.
\end{abstract}

* Corresponding author

E-mail: nirupamasharma999@gmail.com (Nirupama Sharma)

Peer review under responsibility of Journal of Experimental Biology and Agricultural Sciences.

Production and Hosting by Horizon Publisher India [HPI] (http://www.horizonpublisherindia.in/).

All rights reserved.
All the article published by Journal of Experimental Biology and Agricultural Sciences is licensed under a Creative Commons Attribution-NonCommercial 4.0 International License Based on a work at www.jebas.org.

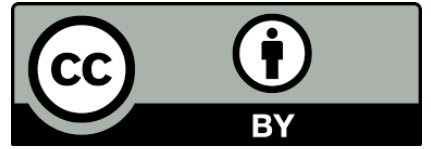




\section{Introduction}

Beekeeping (Apis cerana $\mathrm{F}$.) is a common practice among rural communities in India. Indigenous methods of keeping bee colonies in $\log$ and wall hives are still common in Himachal Pradesh. There was a serious blow to beekeeping with $A$. cerana due to epidemic of Thai sac brood disease in 1984-85, which killed more than 95 per cent of the colonies in the state (Rana, 1987). So far over the world, 18 viruses have been found to infect honey bees. Out of these, Thai sac brood virus and Apis iridescent virus have been found to cause heavy losses to bee industry in India (Abrol, 1993). Further, endoparasitic mite, Acarapis woodi Rennie was first found on A. cerana colonies in Katrain area of Himachal Pradesh (Singh, 1957). Different species of predatory wasps have also been reported to attack A. cerana colonies in India (Painkra, 2018) . The greater wax moth, Galleria mellonella is also reported to be a serious pest of A. cerana indica in hives and stores (Adlakha \& Sharma, 1975). Different pseudoscorpians (Ellingsenius indicus) ants (Camponotus compressus, Dorylus labiams and Monomorium spp.) and birds also attack Apis cerana colonies (Gulati \& Kaushik ,2004)

Management strategies for specific ecological zone can be developed through the understanding of incidence periods of different insect pests, diseases, predators and natural enemies on A. cerana colonies. The present study was therefore undertaken at Katrain area of Kullu valley in Himachal Pradesh and aimed at the recording of different insect pests, predators and other natural enemies attacking A. cerana colonies.

\section{Materials and Methods}

The present investigations were carried out at Regional Horticulture Research Sub-Station of Dr. Y.S. Parmar University of Horticulture and Forestry at Katrain, Kullu (Himachal Pradesh) situated at $32.1^{\circ} \mathrm{N}$ and $77.2^{\circ} \mathrm{E}$ longitude with altitude of $1473 \mathrm{~m}$ amsl. Fifteen colonies, each on 5-6 frames were selected for the present study. Samples of honeybees consisting of larvae, pupae, adults as well as hive debris were collected on monthly basis throughout the study year 2011-12 for the presence of diseases and pests. Organisms collected from debris were identified. Records on the presence of wax moth, pseudoscorpions and ants in the colony were maintained. Observations on activity of predatory wasps and birds were also recorded in the apiary. Thai sac disease was identified from the symptoms prevalent in the colonies (Rana, 1987).

\section{Results and Discussion}

Results of present study have been presented in table 1 . As per the results of present study, colonies were found severely infected with Thai sac brood disease during the whole year. The disease was apparent during August to October months and again in March to July months. During the whole period, 10 colonies absconded due to the disease. Further, colonies and adults were also carefully inspected for the presence of ectoparasitic mites. Adult bees were observed microscopically for the presence of tracheal mite (endoparasitic mite). During whole of the year no parasitic mites were reported in A. cerana colonies. Along with virus and mites, presence of the wax moth larvae (Galleria mellonella) were also reported in the colonies in the months of August - September and February to March months and again during June to July months. Results are in agreement with the findings of Brar et al., (1985) and Gupta (1987), those who found peak activity of wax moths during June to November while Viraktamatha (1989) recorded the peak population during May to August, which coincided with dearth period in South India. Similarly, Adlakha \& Sharma (1975) have also reported Galleria mellonella as a serious pest of A. cerana indica in hives and stores. Incidence of Pseudoscorpion, Ellingsenius indicus

Table 1 : Incidence of various diseases, pests, predators and natural enemies of A. cerana F. at Katrain (District Kullu)

\begin{tabular}{|c|c|c|c|c|c|c|c|c|c|c|c|c|c|}
\hline \multirow{2}{*}{ Category } & \multirow{2}{*}{ Disease/ enemy } & \multirow{2}{*}{$\begin{array}{l}\text { Causative agent/ } \\
\text { common name }\end{array}$} & \multicolumn{11}{|c|}{ Months of incidence (2011) } \\
\hline & & & Aug & Sep. & Oct. & Nov & Dec. & Jan & Feb. & Mar. & Apr. & May & Jun. Ju \\
\hline Microorganisms & Thai Sac brood & Virus & + & + & + & 0 & 0 & 0 & 0 & + & + & + & + \\
\hline Moths & Galleria mellonella $\mathrm{L}$. & Greater wax moth & + & + & 0 & 0 & 0 & 0 & + & + & 0 & 0 & + \\
\hline Wasps & Vespa auraria Smith & Predatory wasp & + & + & + & + & 0 & 0 & 0 & + & + & + & + \\
\hline Pseudoscorpion & $\begin{array}{l}\text { Ellingsenius indicus } \\
\text { Chamberlain }\end{array}$ & & + & 0 & + & + & 0 & 0 & + & + & + & + & + \\
\hline $\begin{array}{l}\text { Ants ( Camponotus } \\
\text { compressus, Dorylus labiams) }\end{array}$ & & & + & + & + & + & 0 & 0 & 0 & 0 & + & + & + \\
\hline Birds & Dicrurus sp. & Predatory bird & + & + & + & 0 & 0 & 0 & 0 & 0 & + & + & + \\
\hline
\end{tabular}

Here + Present; - Absent

Journal of Experimental Biology and Agricultural Sciences

http://www.jebas.org 
Chamberlain was observed in colonies during October and November and then during February - August months. Ants were observed in the colonies for most part of the year.

The only wasp species attacking the A. cerana colonies in Katrain area during the period of observations was Vespa auraria. Its attack was reported during the months of August to November and again during March to July months. Abrol \& Kakroo (1998) have reported five species of wasps attacking A. cerana colonies viz. V. orientalis, V. cincta, V. velutina,. V. magnifica, and V. mandarina.

Predatory bird, Dicrurus $s p$ was found attacking the foraging bees during August - October and then April - July months. Garg \& Kashyap (1998) have also enlisted Dicrurus adsimilis attacking the honeybees. Painkra (2018) have also analyzed the status of different natural enemies which include Greater Wax moth, wasps, ants ,lizard, Chameleon and bears during the months August to May.

\section{Conflicts of interest}

No conflicts of interests are declared by authors for the contents in this manuscript.

\section{References}

Abrol DP (1993) Honeybee virus infection and immunity. Korean Journal on Apiculture 8: 166-118.

Abrol DP, Kakroo SK (1998) Pests, predators and pathogens of honeybee, Apis cerana in Jammu, India. Indian Bee Journal 60: 147-150.
Adlakha RL, Sharma OP (1975) Apis mellifera vs Apis indica. Glean. Bee Culture 103: 160.

Brar HS, Gatoria GS , Jhajj HS, Chahal BS (1985) Seasonal infestation of Galleria mellonella and population of Vespa orientalis in the colonies of Apis cerana apiaries in Punjab. Indian Journal of Ecology 12: 109-112.

Garg R, Kashyap NP (1998) Mites and other enemies of honeybees in India. In: Mishra (Ed.), Perspectives in Indian Apiculture, Agrobotanica, Bikaner,pp 264-303.

Gulati R, Kaushik HD (2004) Enemies of honeybees and their management - a review. Agriculture Review 25:189-200.

Gupta M (1987) Wax moth in Apis mellifera in Haryana, India. Indian Bee Journal 49: 26-27.

Painkra GP (2018) Survey on honeybee diseases and insect pests in Surguja of Chhatisgarh. Indian Journal of Applied Research 8:180-81.

Rana BS (1987) Selective breeding, mating behaviour and sac brood virus disease in Indian hive bee, Apis cerana indica $\mathrm{F}$. Ph. D. Thesis submitted to the University of Shimla, Himachal Pradesh India.

Singh S (1957) Acarine disease in the Indian honeybee (Apis indica F.) Indian Bee Journal 19: 27-28.

Viraktamath S (1989) Incidence of greater wax moth, Galleria mellonella L.in three species of honeybees. Indian Bee Journal 51:139-140.

Journal of Experimental Biology and Agricultural Sciences http://www.jebas.org 